\title{
Exploring Spirituality of Sport for Research in Indonesian Context
}

\author{
Anirotul Qoriah \\ Faculty of Sport Science \\ Universitas Negeri Semarang \\ Semarang, Indonesia \\ anirotulqoriah@mail.unnes.ac.id
}

\begin{abstract}
Sport is a multidimensional phenomenon, encompasses various purposes ranging from health-focused physical activities to spiritual-enhancing practices. Spirituality contributes to a person's well-being, and recent studies begin to examine the potentials to integrate spirituality into the practice of consulting in sport context. Spirituality for some extent is related to religion. In Indonesia where religion is the most important aspect of life, studies in how spirituality contributes to sport performance and athletes' well-being are interesting and beneficial. However, only few studies are found in this topic, and opportunity to do research in this area is still widely open for exploration. As researches need strong theoretical foundation, this article aims to provide information based on literature review about spirituality of sport, its theories and applications. This information is meant to help future researchers and practitioners who intend to promote athletes' performance and well-being by the means of the benefits of spirituality and religion.
\end{abstract}

Keywords—sport, spirituality, literature review

\section{INTRODUCTION}

Religiosity and spirituality (S/R) are a highly investigated topic, denoting how important it is for individuals and society. Eight in ten people in the world are found identifying themselves with religious groups or about $84 \%$ of total world population [1]. Despite of tendency of increased secularity and more people are refusing religion or getting less religious around the world, people still search for spirituality. For example is Americans, 27\% adults think of themselves as spiritual but not religious [2]. Different situation is found in Indonesia, a country with a huge number of religious people, spirituality is expressed within the framework of religion. A survey shows that majority of Indonesian stated that religion has a very important role in society and participate in some rituals [3].

Many studies report how spirituality impacts various aspects of life. Some correlates of spirituality in health outcomes are longer healthy life of older people [4], reduction of mortality rate [5], and mental and physical health [6] [7]. It is known to have effect lowering the rate of heart disease, stroke, kidney failure, and cancer mortality. It lowers cholesterol levels and surgery-related stress, as well as increases positive health habits and longevity [7]. Spirituality also plays important role in coping behavior in facing distressing experience, lowers depression rate, suicide, anxiety, psychotic disorders, and substance abuse [6]. Overall, spirituality has a great contribution to well-being and happiness [8].

In social life, spirituality become predictors of pro-social behaviors, such as volunteering, charitable giving, and helping others, which are contributive for developing moral community [9]. In workplace, this appears in the form of Organizational Citizenship Behavior, indicated by behaviors such as acceptance, assuming additional responsibilities, following the rules and procedures, maintaining and developing positive attitude, and patience and tolerance of dissatisfaction and problem [10]. Due to its practical aspect, spirituality is integrated in health care [11], educational institution [12], in workplace [13], and even sport [14].

Talking about sport, kinds of physical activities comes to mind. Sport is regarded as physical exercise, instrument for health, competition, and championship. Frequently appeared as something physical, sport is more likely less known for having a spiritual facet. Actually, the spirit of sport lies behind every action of athletes and sportsman characterized by working hard, perseverance, and integrity. It is about virtues, values, beliefs, and confidence to something higher than self which influence how athletes and sportsman behave. Spirituality of sport is relatively understudied especially in Indonesia. Therefore, the article is purposed to provide information based on literature review about spirituality of sport, its theories and applications. This review is meant to help sport scientist and practitioner to develop research or application using the concept.

\section{DEFINING SPIRITUALITY}

Spirituality comes from Latin spiritus meaning breath, wind, and life principle. The spirit is the thing within human which is vital and serves as the source of force of life. It is a dynamic reality that expresses itself in the body and organizes body as team. The spirit works in holistic way, meaning integrating cognitive, affective, and physical elements. Therefore, there is no dichotomy between body and soul. The spirit is beyond the self, but it serves as the force that enables and motivates a human being to search for meaning and purpose of life, to search the supernatural or meaning that transcends him, to discover his origin and identity, and to require morality and equity [15]. 
As related to spirit, spirituality is about the practice and outworking of the spirit and the ways in which it is developed, with its different aspects and relationships connected, sustained and understood. Spirituality is relation and actioncentered [15]. In more general definition, Merriam-Webster Dictionary defines, spirituality as the quality or state of being spiritual or sensitivity or attachment to religious values [16]. Due to its close relation to religion, spirituality is often defined as exclusively attached to religion, at least from formal religions' stand point. Spirituality is the practice of worship, devotion, and prayer which enables an awareness of God. Hence, to enhance spirituality, a believer needs a guide (e.g. religious teacher) to help him develop faith and undergo rituals [15].

Spirituality is "a search for the sacred" [17]. The term search indicates that spirituality involves a process and effort to discover the sacred and conserve it. To discover and conserve the sacred, one has to take a so called spiritual pathway. It includes various social involvements that come from traditional religious institution or non-traditional spiritual group (newer spiritual movement). That pathway might consist of religious practice and ritual or other activities aimed to discover the sacred through for example: music, art, yoga, social action, and also sport [17].

However, in a greater sense, spirituality is broader than what is confined by religion. Spirituality relates to acts of reflection and self-development. It is especially stressed by New Age perspective which defines spirituality as a person's attitudes in understanding life through self-reflection which in turn facilitates self-growth and transformation [18].

Spirituality seems liberated from the confine of religious dogma and getting secularized by the new conceptualization. However, it is still relevant for religious people that practicing religion should result in self-growth and transformation. Religion is much meaningful when it involves development of spirituality. Operationally defined, spirituality should consist of three aspects: 1) awareness and appreciation of the other (including the self, the other person, the group, the environment and, where applicable, deity), 2) the capacity to respond to the other by putting spirituality into practice while interacting with others, and 3) developing significant life meaning based upon all aspects of awareness and appreciation of and response to the other [15].

\section{SPIRITUALITY IN SPORT CONTEXT}

Spirituality is more than ideas and aspirations regarding life meaning. It is life experience rooted in beliefs and values. In sport context, spirituality goes beyond individual athletes. It reaches organization and management of sport institution and wider community of sport stakeholders [19].

Generally, spirituality has three focuses. First, it is the search of life meaning, both doctrinal and existential. Spirituality relates to human's need to understand the nature of life and his living environment. However, spirituality is not only about concepts of life, but also one's awareness about himself and awareness about other. It results in acceptance and appreciation to others, willingness to contribute to community and sense of purpose while living with others [19].

Second, spirituality is about religious beliefs and practices. In various religions, historically and theologically, physical exercise and sport are part of religious practice [19]. Cashmore [20] explained that religion and sport is related to each other. For example, the tradition of Olympic game was born in Greek about centuries ago as part of religious festival. Sport contest was aimed to achieve physical excellence, and to please Gods [20] [21] [22].

Third, spirituality is means to promote psychological wellbeing and happiness. Applied spirituality is a new field of study in positive psychology which tries to give contribution in improving individuals and community's well-being. It studies virtues and its manifestation in modern life as long practiced in spiritual traditions from various cultures [19] [23].

In practice, spirituality can be found in various aspects of life. For example, in work place, a worker can be regarded as highly spiritual person due to his tendency to relate his work to life meaning. Work becomes his means to find life meaning. In education, one purpose of learning is spiritual development. In Indonesia, we can see it in Republic Indonesia Law No. 20 Year 2003 on National Education System. Essentially, the purpose of education is to develop the spiritual, moral, cultural, mental and physical development of pupils. In healthcare, spirituality is highly promoted as it has great impact on therapeutic outcomes. Spirituality can serve as buffer against the severity of illness.

The practice of spirituality in sport context is no difference, but with some uniqueness. Unlike in education and healthcare where the development of spirituality becomes conscious concern of the institutions involved, in sport, spirituality is something that is naturally developed through the course of training, exercising, and competition. There are no agents in sport with special duty to guide athletes or sportsman' spirituality, but the development of spirituality is an embedded process in the sport itself.

Since a long time, sport also has been utilized as tool for personal development. The practice of sport is known to enable transformation, liberation, and character development [15]. Spiritual development can be seen as natural part and result of sport. For example, holism of sport always stresses the balance of spirit, mind, and body. The best performance comes from the ability to unite the three faculties. Thus, sporting is more than merely physical working, but activity that touches one's state of mind and emotion, connects him to a meaning of life, and promotes self-growth. That is how sport acts as the center of meaning and purpose, contributing to spiritual development. With sport, a person can experience a holistic experience when body and mind work together to achieve one meaningful purpose, namely excellence [15].

\section{A. Spirituality and Issues in Morality and Ethics}

Relationship between sport and religion is one central topic under the discussion of spirituality of sport. The topic of religion and spirituality in sport context is relevant because 
those two things are often regarded as the source of ethic and morality which are essential in sport.

Competitive nature of sport for some extent is detrimental. Ambition to win at all cost may trigger the willingness to mistreat other (by violence or aggression) or cause hate to opponent for they are the obstacle of ambition. A competition may turn to be like a war where the game is motivated by the desire to beat and destroy the enemy rather than a moral quest for fair play and respect to humanity. Athletes and sportsman may engage in non-ethical behaviors, such as consuming performance-enhancing drugs, deceiving officials, breaking the rules, cheating, committing injustice, and intimidating other players.

The doctrine of "win at all cost" constitutes the spirit of modern sport when sport is separated from religion and spirituality. Modern sport is characterized by secularism. Despite of the tendency to become ritualized and arouse strong emotion, sport is no longer related to the sacred. Sport players tend to be obsessed to surpass previous record and to become phenomenal or to create history [24]. Sport becomes industry which focuses mainly to gain material profit, popularity, and fame. In this environment, ethic and morality are sometimes sacrificed for worldly gains.

From spirituality of sport perspective, this phenomenon can be seen as the symptom of spiritual crisis. Human-being is prone to insecurity and he always try to overcome this problem by a will to power. In sport context, the will to power is achieved primarily by winning. The desire to win may drive people involved in sport, such as athletes, coaches, spectators, and officials, to do anything for the sake of pride, power, or money. When sport is mainly purposed for worldly interest, people would eventually loss many virtues, such as patience, compassion, self-control, humility, and respect [24].

This reality of sport is contradictory to the original spirit of sport which is manifested in the concept of sportsmanship. Sportsmanship refers to the concern and respect for the rules and officials, the opponent, one's full commitment toward sport participation, and social conventions as well as relative absence of negative approach toward one's participation in sport [25]. Sportsmanship which results in fair play actually is rooted in spirituality. Sportsmanship is the manifestation of good spirituality among stakeholders of sport.

The problem regarding morality and ethics implies that religion and spirituality dimension of sport cannot be ignored. Sport originally is integration of the function of mind, body, and spirit so that separating sport from the sacred or spirituality would create imbalance. An athlete is not perfect if he does not have a clear mind and good heart (spirituality), even though he is physically strong and highly skilled. For this reason, cultivating spirituality should be promoted as part of sport education and training whether or not it is associated with religion in practice.

\section{B. Spiritual Experience as Motivation of Sport Participation}

Spirituality influences how athletes and sportsman behave during exercising or engaging in sport. Otherwise, sport and various kinds of physical activities also influence one's spirituality. As known, sport is not only about competition. People participate in sport for various reasons ranging from health, recreation, socialization, to spiritual experience. In other way, sport can be tool for enhancing spirituality.

Sullivan [26] explained that sport and physical activity can evoke the sense of spirituality in a person. Some people participate in outdoor sports (e.g. mountain climbing, rock climbing) to see beautiful natural sceneries, to get in touch with nature and wildness, and finally, to interact with God. In this case, sport becomes a media to seek spiritual experience and to deepen faith. Basically, sport provides some kind environment which enables its participants to sense the existence of God and to experience the sacred. People enjoy sport because it facilitates their spiritual development.

Some studies affirm this finding, for example in surfing which is secular in nature [27]. Spirituality is highlighted not from the kind of sport a person participating in, but the meaning that person attached to the activity. In surfing, environment becomes a key element to experience the sacred. Here, the ocean creates for many surfers a realm of opportunity for transcendental experiences and ultimately enlightenment. When surfing, the surfers feel emotion such as "awe, respect, gratitude and love for the ocean. ... In the surfing realm of belief, the ocean can mean something sacred, revered, feared, respected, appreciated or loved. Surfers also reported a sense of humility and personal empowerment developing out of their oceanic experiences, the former from surrendering to, and the latter from surviving and harnessing, the waves." (p. 32)

\section{Spirituality and Practical Issues in Sport Performance and Consulting}

Applied spirituality in sport context is another important topic regarding how the role of spirituality to solve practical issues. Spiritual well-being is known to be associated with most aspect of good physical and mental health. Athletes who are high in spiritual well-being tend to display better athletic coping skill related to sport performance. Thus, to improve performance, spiritual well-being should be the concern [28].

Watson and Nesti [29] suggested that spirituality should be considered in research and practice of psychological consultation. For some athletes, religious beliefs and spirituality are regarded very influential for their performance and life skill. Spirituality can be integrated in mental skill training for athletes and counseling process.

In other studies, some researchers investigated the use of prayer on athletes. Athletes pray for three main reasons: to overcome uncertainty and anxiety caused by competitive situation, to put life and sport into perspective, and to give meaning to their participation in competition [30]. Also, it is recommended for athletes to improve their praying to cope with anxiety or sadness. Praying is a constructive way to help athletes overcoming their sport-related problems, to help them be more reflective and receptive to learning from mistakes or disappointment [30]. 
Spirituality also plays role in counseling to help athletes facing failure and defeat. Athletes' lives are not only built by strength, tenacity, and hard work, but also ability to sustain personal coherence and resilience in the face of lived experience, both involving success and mastery or failure and defeat. Spirituality is needed to help athletes gaining meaning from their life experience, its achievement and the setbacks and to help them expand their comfort zone [31].

\section{CONCLUSION: RECOMMENDATION FOR FUTURE RESEARCH}

Sport inherently is a holistic activity which is not only influenced by spirituality, but also influences the development of spirituality on people. It is widely recognized that body and soul cannot be separated; there should be no dichotomy between physicality and spirituality. Especially in the context of competitive sport, an athlete's excellence is defined not only by physical strength and skill, but also his mental toughness and integrity which are considered a function of high spirituality. For that reason, integrating spirituality into sport activity is important.

Effort to integrate spirituality to sport which is considered secular activity in modern era is increasing. Various studies has reported positive role of spirituality on developing athletes' morality and ethical behavior, motivating people to participate in sport, and supporting sport practitioners in solving athletes' performance and career problems.

In Indonesia, research under the topic of sport, religion, and spirituality is very limited. In a country whose people are religious and devoted to religions, research in this area should be promoted. Many issues can be addressed for future research, for example: the role of spirituality and religiousness on Indonesian athletes, spirituality and religiousness as part of coping skill, integration of spirituality and religion into sport education and training, and integration of spirituality and religion in sport counseling and consultation.

Collaboration between scientists and practitioners in sport and experts on religious studies should also be supported. This collaboration can be a media for knowledge sharing through research and practice. This effort is almost never done in the past due to a mindset that sport science has no connection with religion and spirituality due to the secular nature of sport science. Connecting sport to religion in Indonesia can be very much relevant since many athletes, coaches, and other stakeholders in sport are people with religion and treating spirituality as important part of their life.

\section{REFERENCES}

[1] Pew Research Center, "The Global Religious Landscape," December 18, 2012, http://www.pewforum.org/2012/12/18/global-religious-landscapeexec/

[2] Pew Research Center, "More Americans now say they're spiritual but not religious," September 6, 2017, http://www.pewresearch.org/facttank/2017/09/06/more-americans-now-say-theyre-spiritual-but-notreligious/
[3] W. Suryana, "PBNU Ungkap Hasil Survei Keberagaman Umat Islam di Indonesia," January 30, 2017, http://khazanah.republika.co.id/berita/dunia-islam/islamnusantara/17/01/30/oklhxs396-pbnu-ungkap-hasil-survei-keberagamanumat-islam-di-indonesia

[4] Z. Zimmer, C. Jagger, C.-T. Chiu, M. B. Ofstedal, F. Rojo, and Y. Saito, "Spirituality, religiosity, aging and health in global perspective: A review," SSM -Population Health vol. 2, pp. 373-381, 2016. . http://dx.doi.org/10.1016/j.ssmph.2016.04.009

[5] G. Lucchetti, A. L. G. Lucchetti, and H. G. Koenig, H. G. "Impact of spirituality/ religiosity on mortality: Comparison with other health interventions," Explore, vol. 7, issue 4, pp. 234-238, 2011. doi:10.1016/j.explore.2011.04.005

[6] H. G. Koenig, "Research on religion, spirituality, and mental health: A review," The Canadian Journal of Psychiatry, vol. 54, issue 5, pp. 283291, 2009.

[7] K. S. Seybold, and P. C. Hill, "The Role of Religion and Spirituality in Mental and Physical Health," Current Directions in Psychological Science, vol. 10, issue 21, pp. 21-24, 2001. doi: 10.1111/14678721.00106

[8] V. M.-C. Lun and M. H. Bond, "Examining the Relation of Religion and Spirituality to Subjective Well-Being Across National Cultures," Psychology of Religion and Spirituality, vol. 5, issue 4, pp. 304-315, 2013. doi: $10.1037 / \mathrm{a} 0033641$

[9] C. J. Einolf, "Daily Spiritual Experiences and Prosocial Behavior," Social Indicators Research, vol. 110, issue 1, pp. 71-87, 2011. https://doi.org/10.1007/s11205-011-9917-3

[10] S. Ahmadi, Y. Nami, and R. Barvarz, "The Relationship Between Spirituality In The Workplace And Organizational Citizenship Behavior," Procedia - Social and Behavioral Sciences, vol. 114, pp. 262264, 2014. doi: 10.1016/j.sbspro.2013.12.695

[11] M. Redford, "Spirituality and education; inner and outer realities," International Journal of Children's Spirituality, vol. 11, issue 3, pp. 385396, 2006. doi: 10.1080/13644360601014130

[12] A. Bussing, K. Baumann, N. C. Hvidt, H. G. Koenig, and C. M. Puchalski, "Spirituality and health. Evidence-Based Complementary and Alternative Medicine," 2014. http://dx.doi.org/10.1155/2014/682817

[13] S. T. Carroll, "Addressing religion and spirituality in the workplace," APA handbooks in psychology. APA handbook of psychology, religion, and spirituality (Vol. 2): An applied psychology of religion and spirituality, K. I. Pargament, A. Mahoney, \& E. P. Shafranske (Eds.), Washington, DC, US: American Psychological Association, 2013, pp 595-612. . http://dx.doi.org/10.1037/14046-031

[14] I. Jirásek, "Religion, spirituality, and sport: from religio athletae toward spiritus athletae," Quest, vol. 67, issue 3, pp. 290-299, 2015.

[15] S. Robinson, "Spirituality: A working definition," in Sport and spirituality: An introduction, N. J. Watson \& M. Nesti, Eds. London: Routledge, 2007, pp. 22-37.

[16] Spirituality, Merriam-Webster Online Dictionary, 2008. http://www.merriam-webster.com/dictionary/spirituality

[17] K. I. Pargament and A. Mahoney, "Spirituality: Discovering and conserving the Sacred," in Handbook of Positive Psychology, C. R. Snyder and S. J. Lopez, Eds. New York: Oxford University Press, 2002, pp. 646-659.

[18] S. Robinson, "Spirituality: A story so far," in Sport and spirituality: An introduction, J. Parry, S. Robinson, N. J. Watson, and M. Nesti, Eds. London: Routledge, 2007, pp. 7-21.

[19] J. Parry, S. Robinson, N. J. Watson, and M. Nesti, "Sport and spirituality: An introduction," London: Routledge, 2007.

[20] E. Cashmore, "Sport psychology: The key concepts," London: Routledge, 2002.

[21] S. C. Murray, "The Role of Religion in Greek Sport," in A Companion to Sport and Spectacle in Greek and Roman Antiquity, P. Christensen and D. G. Kyle, Eds. West Sussex: Blackwell \& John Wiley \& Sons, 2014.

[22] G. Papantoniou, "Religiosity as a main element in the ancient Olympic games," Sport in Society: Cultures, Commerce, Media, Politics, vol. 11, issue $\quad 1 ., \quad 2007$ http://www.tandfonline.com/doi/abs/10.1080/17430430701717665\#.Uq yhdfRdUy4. 
[23] C. R. Snyder and S. J. Lopez, "Handbook of Positive Psychology," New York: Oxford University Press, 2002.

[24] N. J. Watson and J. White, "'Winning at all costs' in modern sport: Reflection on pride and humility in the writings of C. S. Lewis," in Sport and spirituality: An introduction, J. Parry, S. Robinson, N. J. Watson, and M. Nesti, Eds. London: Routledge, 2007, pp. 61-79.

[25] R. J. Vallerand and G. F. Losier, "Self-determined motivation and sportsmanship orientations: An assessment of their temporal relationship," Journal of Sport and Exercise Psychology, vol. 16, pp. 229-245, 1994.

[26] S. P. Sullivan, "God in my sporting: A justification for Christian experience in sport," Journal of the Christian Society for Kinesiology and Leisure Studies, vol. 1, issue 1, pp. 9-17, 2010. http://cskls.org/wpcontent/uploads/2012/11/God_in_my_sporting_Sullivan1.pdf

[27] L. Kerby, "Surfing and spirituality," Social Sciences Capstone Projects. Paper 6 , 2010. https://commons.pacificu.edu/cgi/viewcontent.cgi?referer=https://schola r.google.co.id/\&httpsredir=1\&article $=1005 \&$ context=cassoc
[28] H. Ridnour and J. Hammermeister, "Spiritual well-being and its influence on athletic coping profiles," Journal of Sport Behavior, vol. 31 , issue 1, pp. 81-92, 2008.

[29] N. J. Watson and M. Nesti, "The role of spirituality in sport psychology consulting: An analysis and integrative review of literature," Journal of Applied Sport Psychology, vol. 17, issue 3, pp. 228-239, 2005.

[30] N. J. Watson and D. R. Czech, "The use of prayer in sport: Implications for sport psychology consulting," The Online Journal of Sport Psychology, vol. 7, issue 4, pp. 26-35, 2005. http://www.athleticinsight.com/Vol7Iss4/PrayerPDF.pdf

[31] R. Hutch, "Sport and spirituality: Mastery and failure in sporting lives," Practical Theology, vol. 5, issue 2, pp. 131-152, 2015. https://doi.org/10.1558/prth.v5i2.131 